\title{
Studying Features of Vehicle Type Selection by Trade and Logistics Enterprise*
}

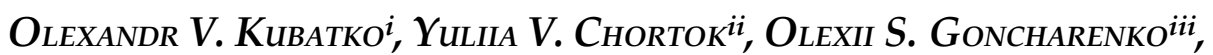 \\ RoMAN M. NeCHYPorenKo ${ }^{i v}$, INNA M. MOSKALENKo ${ }^{v}$
}

An analysis of Ukraine's foreign economic activity showed that exports and imports of Ukraine in 2018 increased by $\$ 4.08$ billion and $\$ 12.9$ billion. In the geographical structure of the countriesimporters of Ukrainian goods the largest share is occupied by the countries of the European Union, which testifies to the improvement of the quality level of domestic products. This study is devoted to the analysis of the peculiarities of the transport logistics organization, namely the process of delivery of "Biola" juice (apple juice) with a volume of 1 liter at the order of LLC "Trading House "Biola" to Poland. Road transport in Ukraine carries $64 \%$ of cargo.The rules of transportation of the given cargo and features of its packing are considered. It is proved that in order to organize an efficient and clear delivery process, especially if the delivery is performed internationally, and also involvings the organization of loading and unloading works, it is necessary to clearly form a transport and technological scheme of delivery of cargo. Transportation of juice in bottles is allowed by any covered transport or in universal containers, and it is mandatory to keep the cargo away from direct sunlight. Juice has a liquid state by its physical condition, so it is placed in a packaging of the appropriate size for convenience. The scheme of placement of juice packages with dimensions $270 * 180 * 280 \mathrm{~mm}$ and gross weight of $6.1 \mathrm{~kg}$ been developed on lightweight Euro pallet with dimensions $1200 * 800 \mathrm{~mm}$ has. Possible schemes of placement of pallets with juice of $1200 * 800 * 1540 \mathrm{~mm}$ in the SCHMITZ CARGOBULL SCS 18 semitrailer with internal body dimensions of $7720 * 2480 * 3000 \mathrm{~mm}$ are considered. It is determined that the scheme will be optimal, in which the car body is placed 18 pallets.

Keywords:-cargo, export, juice, pallete, transport, transportation.

Introduction. In the twenty-first century, every economic field has undergone global changes. Many branches of science and entrepreneurships have lost their relevance, while vehicle has always been and will always be a priority in the economy, since without the

${ }^{i}$ Olexandr V. Kubatko, Dr. (Economics), Professor, Department of Economics, Enterpreneurship and BusinessAdministration, Sumy State University;

${ }^{i i}$ Yuliia V. Chortok, C.Sc. (Economics), Associate Professor, Department of Economics, Enterpreneurship and Business-Administration, Sumy State University;

iii Olexii S. Goncharenko, C.Sc. (Economics), Seniour Lecturer, Department of Economics, Enterpreneurship and Business-Administration, Sumy State University;

${ }^{i v}$ Roman M. Nechyporenko, Postgraduate Student of the Department of Economics, Enterpreneurship and Business-Administration, Sumy State University;

${ }^{v}$ Inna M. Moskalenko, Student of Oleg Balatskyi Academic and Research Institute of Finance, Economics and Management, Sumy State University.

* The material is prepared according to the research work "Corporate Social and Environmental Responsibility for Sustainable Development: Stakeholders Partnership in the Real, Financial and Public Sectors of the Economy”, which is funded by the Grant from the Ministry of Education and Science of Ukraine (No of state registration 0117U003933).

(C) O. V. Kubatko, Yu. V. Chortok, O. S. Goncharenko, R. M. Nechyporenko, I. M. Moskalenko, 2019.

https://doi.org/10.21272/mer.2019.85.07

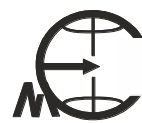


normal functioning of transport, further development of the economic, sociocultural and financial spheres of the economy is impossible. Thus, the level of transport development is today a decisive factor in determining volumes of exports and imports, and as a result, it determines the GDP and citizens' living standards.

In 2018, the World Bank published an updated Logistics Performance Index (LPI) rating, in which Ukraine has risen by 14 positions comparison to 2016 (rating is published every second year). The rating is made up of five areas and the result is the level of road transport infrastructure development. The rating is an indication that road haulage in Ukraine has begun to develop and become a priority in recent years. Road transport in Ukraine carries $64 \%$ of cargo. Therefore, we believe that the study of road haulage is especially relevant today.

Problem statement. In 2018, the countries of the European Union became the main economic partners of Ukraine. Among them, Poland is the main importing country of Ukrainian goods (the share in the export structure was $31.4 \%$ ). Since Ukraine-Poland road haulage is a prominent part of Ukraine's foreign economic activity, there is an urgent need to improve the organization's efficiency of transportation in this direction. Increasing the efficiency of Ukraine-Poland road haulage can be achieved by reducing driving time, using more environment-friendly rolling stock and haulage organization on the basis of new routes.

The following scientists were involved in improvement and development of transport logstics methods: Govorukha [1], Krykavskyy [4], Mukhtarova [5], Velychko [9], Zielińska [10] etc. In our study, we will focus more on the practical aspects of cargo delivery.

The purpose of the research is to analyze the transportation product features, such as the selection of the mode of transport, taking into account different requirements.

Results of the research. Since 2008, Ukraine has been drawn into the global economic crisis, the consequences of which we still see. As a result of this crisis, Ukraine's economic performance has deteriorated significantly.

One of the most significant reasons for the deterioration of Ukraine's macroeconomic situation was the decline in exports and the significant increase in imports, which is still largely dominant in the structure of the country's foreign economic dynamics.

Analyzing the last 5 years in the sphere of foreign economic activity, it is worth emphasizing the importance of implementing preferences for domestic producers on export certain groups of goods to the countries of the European Union. However, if you look at the performance of goods exports in recent years (Fig. 1), we see that, unfortunately, this decision did not change the situation with the prevalence of imports in the economic life of Ukraine.

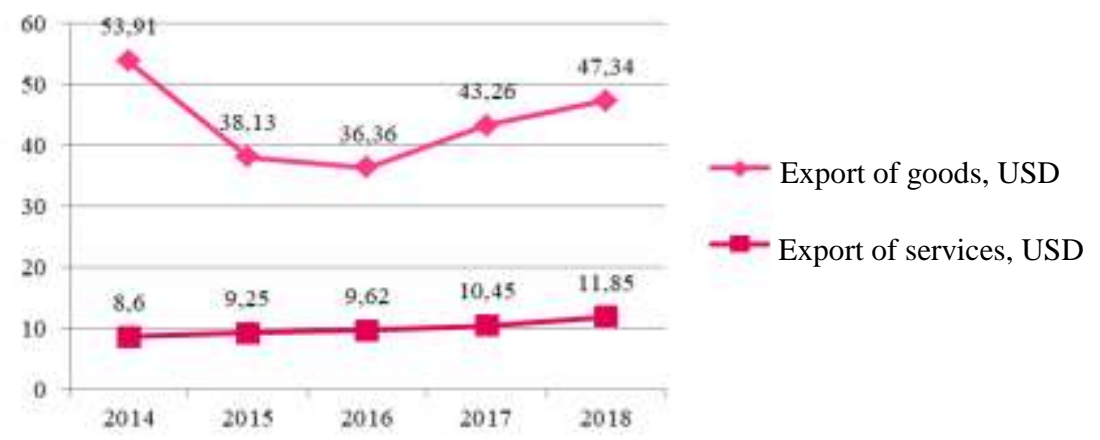

Figure 1. Dynamics of exporting goods and services between 2014 and 2018 accounts for $\$ 1$ billion 
Olexandr V. Kubatko, Yuliia V. Chortok, Olexii S. Goncharenko, Roman M. Nechyporenko, Inna M. Moskalenko. Studying Features of Vehicle Type Selection by Trade and Logistics Enterprise

In terms of exports, commodities, agricultural products and some services which are particularly in the high-tech sector, remain the main items of domestic exports. According to the World Bank, the share of exports of high-tech products from Ukraine in total exports has been 7-8\% over the last three years. Thus, this indicator has tripled in the last 3 years. In terms of the share of exported agricultural products, Ukraine still remains an agrarian country, as this indicator made up about $19 \%$ of the total export share.

Goods that have not been processed or have been processed minimally, that is, primary ones (metals, minerals, crop and livestock production) are of a high percentage of exporting goods.

In 2018, according to the official website of State Statistics Service of Ukraine, $15.5 \%$ of all exported goods were sent to Poland, $10 \%$ to Germany, $9.6 \%$ to the Netherlands.

Experts estimate the situation with increasing export volumes to the EU countries as stable, while reducing exports to Russia is now logical and inevitable, since from the beginning of 2019 the Ukrainian government introduced a number of new sanctions against the aggressor country.

Thus, although the dynamics of export growth is slower than it was expected by the experts while changing the economic course of Ukraine entirely to the European Union, it is still quite stable and positive. Import volumes still prevail significantly in the country's external economy.

The rate of decline in imports and exports to Russia is much slower, although it was expected that the expansion of sanctions list would make economic relations between Ukraine and Russia weaker by the beginning of 2019. Due to the fact that the expected result was not achieved, since August 2019 Ukraine has already expanded the list of banned importers from Russia .

To study the process of choosing a vehicle, it was chosen the juice delivery process, which is performed by "Your Logistics" LLC by request of LLC "Trade House "Biola", namely, "Biola" juice (apple juice), 1 liter in volume. "Your Logistics" LLC is a well-known company in the field of providing logistic and brokerage services to subjects of foreign economic activity. The company's infrastructure is well developed, which is the main advantage of "Your Logistics" LLC over similar domestic companies. The infrastructure, in addition to the Kiev offices, is represented by 5 offices in the Odessa city and in ports, namely in the Black Sea and Illichivsk seaports, as well as areas of its own customs warehouses.

In Ukraine, the company is the only one that has its own representative offices at all checkpoints. In addition, "Your Logistics" LLC has its own representative offices and warehouses in Beijing, as well as in Poland, Belarus, Moldova, Germany and the USA ( 2 offices), as well as its own customs warehouses, central sorting stations with a total area of more than $2500 \mathrm{~m} 2$ around the world.

Let's analyze the features of the goods being transported. Juice is a break-bulk cargo related to the products of food industry.

Juice has a liquid state by its physical condition, so it is placed in a packaging of the appropriate size for convenience. This product is transported in plastic bottles made of PET plastic (i.e., intended for single use). "Biola" apple juice refers to restored juices, that is, it is made from purified water and concentrated juice. According to the production technology, it lacks preservatives and artificial colors.

Moreover, the juice is pasteurized, and therefore even without preservatives and artificial colors, its shelf life is 12 months, and storage of the closed bottle in the avoidance of direct sunlight is allowed at a temperature of +1 to $+250 \mathrm{C}$. Thus, according to the current legislation 
[8], the use of isothermal mobile transport is optional for this type of cargo and is determined at the consignor's discretion.

LLC "Trade House "Biola" does not use isothermal vehicles for transporting goods in the international Ukraine-Poland traffic.

It would also be appropriate to provide a complete classification of the cargo, since in the following chapters the classification points will determine the management decisions that are made during transportation.

The classification looks like:

- by type of tare - tare cargo;

- by weight - normal (normal mass, since the weight of a unit of goods is $1 \mathrm{~kg}$ );

- by overall dimensions - overall cargo;

- according to the way of loading and unloading - break-bulk (packaged) cargo;

- by type of production (by industry) the product belongs to the food industry;

- by physical condition - the product belongs to liquid cargo;

- according to the degree of use of the vehicle's carrying capacity, uncarbonated bottled beverages belong to the 2 nd class of cargo;

- according to its specific properties - the cargo is not specific, since it does not require special conditions during transportation and storage. However, the maximum temperature threshold for juice storage is set from +1 to $+250 \mathrm{C}$.

Consider the rules of juice transportation.

First of all, juice bottles are not transported in units; according to the standard rules, they packed in thermo-shrinkable film ( 6 bottles in one pack), as shown in Fig. 2. To facilitate loading and unloading operations, LLC "Trade House "Biola" usually puts bottles on GT1 cardboard. However, the packaging requirements for juice bottles are absent and stated in DSTU 4283.1: 2007 only as "recommended" and not "mandatory", and therefore they remain solely at the consignor's discretion.

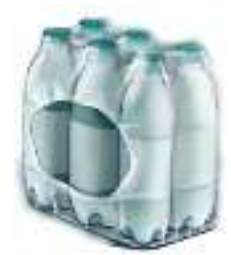

Figure 2. Schematic of bottles in thermostatic packaging and loaded pallet

The packaging with bottles is placed on pallets, the height of the stack is not regulated by the rules of transportation / storage. The number of packages with goods on a pallet is taken according to the principle of their multiplicity to the pallet dimensions (schematic image in Fig. 2.). After installation on a pallet, they are fixed with a stretch film to ensure the integrity of the consumer tara and to increase maneuverability during unloading. Pallets are placed between themselves, providing the minimum possible intervals.

The pallets are reloaded with standard forklifts or (less commonly) pallet jack.

During storage and transportation of cargo it shoul be provided a relative humidity - not higher than $70 \%$ and an optimum temperature - not higher than $+250 \mathrm{C}$. A mandatory requirement for transportation and storage is to avoid direct sunlight. In case of overloading, the cargo is forbidden to turn over [2,3].

Transportation of juice in bottles is allowed by any covered transport or in universal containers, and it is mandatory to keep the cargo away from direct sunlight. 
Olexandr V. Kubatko, Yuliia V. Chortok, Olexii S. Goncharenko, Roman M. Nechyporenko, Inna M. Moskalenko. Studying Features of Vehicle Type Selection by Trade and Logistics Enterprise

Accordingly, while loading juice in packages and putting it on pallets, one should adhere to the general rules of loading for a particular type of transport. It is forbidden to transport or store the cargo next to other cargoes, which can damage the organoleptic or physico-chemical properties of the juice. The height of the stack should not exceed $1.6 \mathrm{~m}[6,7]$. Lightweight pallets are used for transporting bottles, since the packaging with bottles has a small weight of its own, the use of lightweight pallets is more economically feasible.

So, the specified type of cargo is packed in packages with overall dimensions of $270 * 180 * 280 \mathrm{~mm}$ on lightweight Euro-pallets with overall dimensions of $1200 * 800 \mathrm{~mm}$. Below are the necessary calculations to determine the layout of boxes on the Euro-pallets. The calculation results are presented in table 1 .

Layout scheme of packages on a lightweight Euro-pallete $(1200 * 800)$,

Table 1 provided that the cargo cannot be turned over

\begin{tabular}{|c|c|c|c|c|c|c|c|c|}
\hline \multirow{2}{*}{ No } & \multirow{2}{*}{ Layout scheme } & \multicolumn{4}{|c|}{ Number of units } & \multirow{2}{*}{$\begin{array}{l}\text { Actual load capacity } \\
\text { of the Euro-pallet, kg }\end{array}$} & \multicolumn{2}{|c|}{ Utilization factor } \\
\hline & & $\mathrm{L}$ & $\mathrm{B}$ & $\mathrm{H}$ & $\mathrm{N}_{3 \mathrm{ar}}$ & & $\gamma_{\mathrm{cT}}$ & $\eta \mathrm{s}$ \\
\hline 1 & $\mathrm{~L} \backslash \mathrm{l}, \mathrm{B} \backslash \mathrm{b}, \mathrm{H} \backslash \mathrm{h}$ & 4 & 4 & 5 & 80 & 488 & 0,53 & 0,81 \\
\hline 2 & $\mathrm{~L} \backslash \mathrm{b}, \mathrm{B} \backslash \mathrm{l}, \mathrm{H} \backslash \mathrm{h}$ & 6 & 2 & 5 & 50 & 320 & 0,32 & 0,61 \\
\hline
\end{tabular}

Calculation of the main indicators of loading packages on the pallet:

- according to the scheme 1.L $\mathrm{l}, \mathrm{B} \backslash \mathrm{b}, \mathrm{H} \backslash \mathrm{h}$ :

Determine the multiplicity indicators of packages on the Euro-pallet:

$$
\begin{aligned}
& \text { for } L: 1200 / 270=4,4=4(p c) \text {; } \\
& \text { for B: } 800 / 180=4,4=4(p c) \text {; } \\
& \text { for } H: 1600 / 280=5,7=5(p c) \text {; }
\end{aligned}
$$

Number of packages on the Euro-pallet:

$$
\mathrm{N}_{3 \mathrm{ar}}=\mathrm{n}_{1} \times \mathrm{n}_{\mathrm{b}} \times \mathrm{n}_{\mathrm{h}}=4 \times 4 \times 5=80 \text { (packages); }
$$

Gross weight of Euro-pallet:

$$
\mathrm{M}_{\text {бр }}=\mathrm{N}_{\text {заг }} \times \mathrm{m}_{\text {уп }}+\mathrm{m}_{0}=80 \times 6,1+15=503(\kappa \Gamma),
$$

where $\mathrm{m}_{0}$ is the unladen mass of the pallet.

The utilization rate of the load capacity of the pallet:

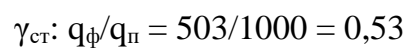

where $\mathrm{q}_{\phi}$ - the actual load capacity of the Euro-pallet, $\mathrm{kg} ; \mathrm{q}_{п}$ - nominal load capacity, $\mathrm{kg}$.

Pallet utilization rate:

$$
\eta_{\mathrm{s}}: \mathrm{S}_{\mathrm{B}} / \mathrm{S}_{\Pi}=(0,27 \times 0,18 \times 4 \times 4) /(1,2 \times 0,8)=0,81 .
$$


О. В. Кубатко, Ю. В. Чорток, О. С. Гончаренко, Р. М. Нечипоренко, І. М. Москаленко.

Дослідження особливостей вибору виду транспортного засобу торговельно-логістичним підприсмством

- according to the scheme 2 . $\mathrm{Llb}, \mathrm{B} \backslash \mathrm{l}, \mathrm{H} \backslash \mathrm{h}$ :

for L: $1200 / 180=6,6=6(\mathrm{pc})$;

for B: $800 / 270=2,9=2(\mathrm{pc})$;

for $\mathrm{H}: 1600 / 280=5,7=5(\mathrm{pc})$;

Gross weight: $\mathrm{N}_{3 \mathrm{ar}}=6 \times 2 \times 5=50$ (packages);

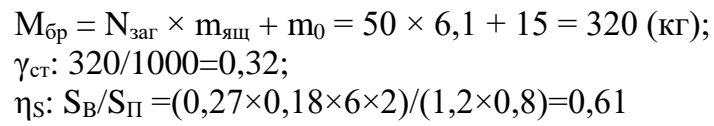

According to both indicators - the degree of utilization of cargo and the area of the pallet we choose the layout scheme №1. Layout of the packages on the pallet is shown in Fig. 3. Dimensions of the formed cargo place $1200 * 800 * 1540 \mathrm{~mm}$.

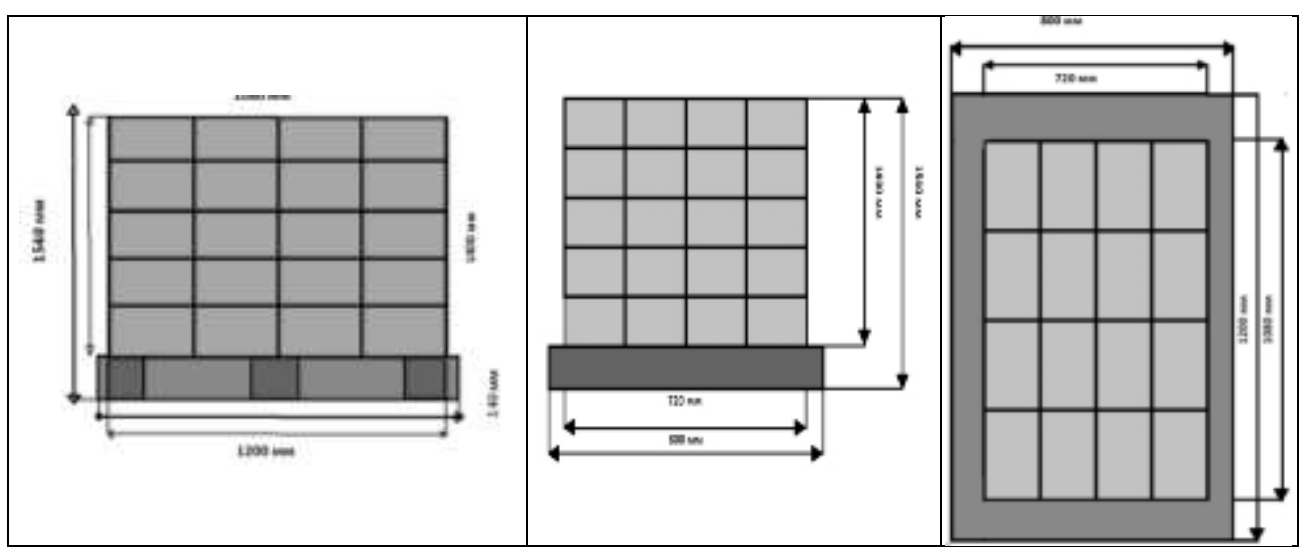

Figure 3. Schematic of the juice packaging arrangement $(270 * 180 * 280 \mathrm{~mm})$ on the lightweight pallet $(1200 * 800 * 140 \mathrm{~mm})$

The truck selected for delivery is MANTGX24.400 tractor and SCHMITZ CARGOBULL SCS 18 semi-trailer. The tractor and semi-trailer of this model belong to the its own rolling stock of "Your Logistics" LLC. The technical characteristics of the tractor and semi-trailer are given in Table 2 and Table 3.

Table 2

Brief technical characteristics of the selected truck tractor

\begin{tabular}{|c|c|}
\hline Indicator name & Characteristic \\
\hline 1 & 2 \\
\hline Make / model & VOLVO FH500 \\
\hline Engine & Diesel \\
\hline Transmission & Manual / mechanical \\
\hline Wheel formula & Euro 6 \\
\hline Euro-standard & $368 \mathrm{kWh}$ \\
\hline Engine power & $900 \mathrm{~L}$ \\
\hline Tank capacity & $19000 \mathrm{~kg}$ \\
\hline Load capacity & \\
\hline
\end{tabular}


Olexandr V. Kubatko, Yuliia V. Chortok, Olexii S. Goncharenko, Roman M. Nechyporenko, Inna M. Moskalenko. Studying Features of Vehicle Type Selection by Trade and Logistics Enterprise

The selected truck tractor, in addition to its heavy load capacity, also has a high environmental standard, therefore it is fully suitable for juice delivery in the international traffic.

Table 3

Brief technical characteristics of the semi-trailer

\begin{tabular}{|c|c|}
\hline Indicator name & Characteristic \\
\hline Make / model & SCHMITZ CARGOBULL SCS 18 \\
\hline Load capacity & 2 axles, SAF \\
\hline Number and type of axles & Disc \\
\hline Brakes & 4 \\
\hline Number of wheels & $7720 * 2480 * 3000 \mathrm{~mm}$ \\
\hline Internal dimensions & \\
\hline
\end{tabular}

The selected semi-tractor has a body frame of the "curtain" type, which facilitates its unloading, and the curtain material completely protects the cargo from direct sunlight, keeps the cargo within the permissible temperature.

Conclusions and prospects of further research. It was determined that Poland, according to 2018 , is the largest importer of juice from Ukraine. Using the Excel software, it was performed forecasting the volume of transportation of this cargo for 2019-2021. The forecasting results suggest that the volume of juice exports to Poland tends to increase.

Taking into account the overall dimensions of the packaging unit $(270 * 180 * 280 \mathrm{~mm})$ and the overall dimensions of the lightweight Euro-pallet $(1200 * 800 \mathrm{~mm})$, it was developed the layout scheme of the packaging on the pallet. It was determined that on the pallet can be placed 80 packages with bottles of juice. It was considered all possible options for the layout schemes of pallets with juice with dimensions of $1200 * 800 * 1540 \mathrm{~mm}$ in the SCHMITZ CARGOBULL SCS 18 semi-trailer with an internal body size of $7720 * 2480 * 3000 \mathrm{~mm}$. It was also determined that the scheme in which the body of the car contains 18 pallets will be optimal.

\section{References}

1. Govorukha, V., Kuchkova, O. (2018). An Estimation of the Logistics Potential of Enterprises in the Region's Management, Montenegrin Journal of Economics, 14(2), 79-89, http://doi.org/10.14254/1800-5845/2018.14-2.5.

2. Konservi. Soki ta sokovI produkti. Nomenklatura: DSTU 4283.1:2007) [Canned food. Juices and juice products. Nomenclature: DSTU 4283.1: 2007 (2007 - 04 - 04)]. National standard of Ukraine State Consumer Standard of Ukraine, 2007.

3. Konservi. Soki ta sokovI produkti. Nomenklatura: DSTU 4283.1:2007 [Canned food. Juices and juice products. Nomenclature: DSTU 4283.1: 2007 (2007 - 08 - 01)]. National standard of Ukraine State Consumer Standard of Ukraine, 2007.

4. Krykavskyi, Y. V. (2004). Lohistyka [Logistics]: Osnovy teori, Lviv Polytechnic National University, Intelekt-zakhid, 416.

5. Mukhtarova, K. S., Trifilova, A. A., Zhidebekkyzy, A. (2016). Commercialization of Green Technologies: An Exploratory Literature Review. Journal of International Studies, 9(3), 75-87. http://doi.org/10.14254/2071-8330.2016/9-3/6.

6. PilomaterIali hvoynih porid. Tehnichni umovi: DSTU 8486-86 [Softwood lumber. Specifications: DSTU 8486-86 (1988 - 01-01)]. National standard of Ukraine - State Consumer Standard of Ukraine, 1988.

7. PilomaterIali hvoynih porid. Tehnichni umovi: DSTU 2695-83 [Softwood lumber. Specifications: DSTU 2695-83 (1984 - 01-01)]. National standard of Ukraine - State Consumer Standard of Ukraine, 1984. 
О. В. Кубатко, Ю. В. Чорток, О. С. Гончаренко, Р. М. Нечипоренко, І. М. Москаленко.

Дослідження особливостей вибору виду транспортного засобу торговельно-логістичним підприсмством

8. Pravila perevezennya shvidkopsuvnih vantazhiv: zi zminami vid 08.06.2011 roku [Rules for the carriage of perishable goods: as of 08.06.2011]. Retrieved from https://zakon.rada.gov.ua/laws/show/z1031-02. (Available at 03.09.2019).

9. Velychko, O., Velychko, L. (2017). Logistical modelling of managerial decisions in social and marketing business systems. Journal of International Studies, 10(3), 206-219. http://dx.doi.org/10.14254/2071-8330.2017/10-3/15.

10. Zielińska, A., Prudzienica, M., Mukhtar, E., Mukhtarova, K. (2016). The examples of reverse logistics application in inter-sector partnerships - good practices. Journal of International Studies, 9(3), 279-286. DOI: 10.14254/2071-8330.2016/9-3/22.

Manuscript received 21 Aughust 2019

Исследование особенностей выбора вида транспортного средства торгово-логистическим предприятием

\section{АЛЕКСАНДР ВАСИЛЬЕВИЧ КУБАТКО*, ЮлИЯ ВЛАДИМИРОвнА ЧоРток ${ }^{* *}$ АЛЕКСЕЙ СЕРГЕЕВИЧ ГОНЧАРЕНКО ${ }^{* * *}$, РОМАН НИКОЛАЕВИЧ НЕЧИПОРЕНКО ИННА НИКОЛАЕВНА МОСКАЛЕНКО ${ }^{* * * * *}$}

* доктор экономических наук, профессор, доцент кафедры экономики, предпринимательства и бизнес-администрирования Сумского государственного университета, ул. Р.-Корсакова, 2, г. Сумы, 40007, Украина,

тел.: 00-380-542-332223, e-mail: okubatko@econ.sumdu.edu.ua

*** кандидат экономических наук, доцент, дочент кафедры экономики, предпринимательства и бизнес-администрирования Сумского государственного университета, ул. Р.-Корсакова, 2, г. Сумыл, 40007, Украина тел.: 00-380-542-332223, e-mail: yulijachortok@gmail.com

*** кандидат экономических наук, стариий преподаватель кафедры экономики, предпринимательства и бизнес-администрирования Сумского государственного университета, ул. Р.-Корсакова, 2, г. Сумы, 40007, Украина тел.: 00-380-542-332223,e-mail: o.goncharenko@econ.sumdu.edu.ua

\footnotetext{
****aспирант кафедры экономики, предпринимательства и бизнес-администрирования

Сумского государственного университета,

ул. Р.-Корсакова, 2, г. Сумы, 40007, Украина тел.: 00-380-542-332223, e-mail: roman.nechyporenko.sumy@gmail.com

****** студентка Учебно-научного института финансов, экономики и менеджмента имени Олега Балацкого Сумского государственного университета, ул. Р.-Корсакова, 2, г. Сумы, 40007, Украина
}

Анализ внешнеэкономической деятельности Украины показал, что экспорт и импорт Украины в 2018 году вырос на 4,08 млрд долларов и 12,9 млрд долларов. В географической структуре стран-импортеров украинских товаров наибольшую долю занимают страны Европейского Союза, что свидетельствует об улучшении уровня качества отечественной продукции. Данное исследование посвящено анализу особенностей организации транспортной логистики, а именно процесса доставки сока «Биола» (яблочного сока) объемом 1 литр по заказу ООО «Торговый Дом «Биола» в Польшу. Автомобильные перевозки по Украине перевозят 64 \% груза. Рассмотрены правила перевозки данного груза и особенности его упаковки. Доказано, что для организации 
Olexandr V. Kubatko, Yuliia V. Chortok, Olexii S. Goncharenko, Roman M. Nechyporenko, Inna M. Moskalenko. Studying Features of Vehicle Type Selection by Trade and Logistics Enterprise

эффективного и понятного процесса доставки, особенно если доставка осуществляется на международном уровне, и также, предполагающий организацию погрузочно-разгрузочных работ, необходимо четко сформировать транспортно-технологическую схему доставки груза. Перевозка соков в бутылках разрешается любым крытым транспортом или в универсальных контейнерах, и обязательно хранить груз вдали от прямых солнечных лучей. Сок имеет жидкое состояние по своему физическому состоянию, поэтому для удобства его помещают в упаковку соответствующего размера. Схема размещения сока пак Кейджи с размерами 270*180*280 мм и массой брутто 6,1 кг разработаны на легком европейском поддоне с размерами $1200 * 800$ мм. Рассмотрены возможные схемы размещения поддонов с соком $1200 * 800 * 1540$ мм в полуприцепе SCHMITZ CARGOBULL SCS 18 с внутренними размерами кузова 7720*2480*3000 мм. Определено, что схема будет оптимальной, в которой в кузов автомобиля помещается 18 поддонов.

Ключевые слова: груз, сок, паллет, транспорт, транспортировка.

$$
\begin{gathered}
\text { Mechanism of Economic Regulation, 2019, No 3, 73-82 } \\
\text { ISSN 1726-8699 (print) }
\end{gathered}
$$

\section{Дослідження особливостей вибору виду транспортного засобу} торговельно-логістичним підприємством

\section{КУБАТКО ОЛЕКСАНДР ВАСИЛЬОВИЧ“, ЮЛІя ВолодиМИРІвНА ЧоРТОК ${ }^{* *}$, ОЛЕКСІЙ СЕРГИЙОВИЧ ГОНЧАРЕНКО ***, РОМАН МИКОЛАЙОВИЧ НЕЧИПОРЕНКО ${ }^{* * * *}$, ІННА МИКОЛАЇВНА МОСКАЛЕНКО}

* доктор економічних наук, професор, доцент кафедри економіки, підприємництва та бізнес-адміністрування Сумського державного університету, вул. Р.-Корсакова, 2, м. Суми, 40007, Україна,

тел.:00-380-542-332223, e-mail: okubatko@econ.sumdu.edu.ua

** кандидат економічних наук, доцент, доцент кафедри економіки, підприємництва та бізнесадміністрування Сумського державного університету, вул. Р.-Корсакова, 2, м. Суми, 40007, Украӥна, тел.: 00-380-542-332223, e-mail: yulijachortok@gmail.com

**** кандидат економічних наук, стариий викладач кафедри економіки, підприємниитва та бізнесадміністрування Сумського державного університету, вул. Р.-Корсакова, 2, м. Суми, 40007, Украӥна,

тел.: 00-380-542-332223, e-mail:o.goncharenko@econ.sumdu.edu.ua

**** аспірант кафедры кафедри економіки, підприємництва та бізнес-адміністрування Сумського державного університету, вул. Р.-Корсакова, 2, м. Суми, 40007, Украйна,

тел.: 00-380-542-332223, e-mail: roman.nechyporenko.sumy@gmail.com

****** студентка Навчально-наукового інституту фінансів, економіки і менеджменту імені Олега Балацького Сумського державного університету, вул. Р.-Корсакова, 2, г. Суми, 40007, Украӥна e-mail:imoskalenko708@gmail.com

Аналіз зовнішньоекономічної діяльності України показав, що експорт та імпорт України в 2018 році збільшилися на 4,08 млрд доларів і 12,9 млрд доларів. У географічній структурі країн- 
О. В. Кубатко, Ю. В. Чорток, О. С. Гончаренко, Р. М. Нечипоренко, І. М. Москаленко. Дослідження особливостей вибору виду транспортного засобу торговельно-логістичним підприсмством

імпортерів українських товарів найбільшу частку займають країни Свропейського Союзу, що свідчить про поліпшення рівня якості вітчизняної продукції. Це дослідження присвячене аналізу особливостей транспортної логістичної організації, а саме процесу доставки соку «Біола» (яблучний сік) об'ємом 1 літр на замовлення ТОВ «Торговий дім« Біола »до Польщі. Дорожній транспорт по Україні перевозить 64 \% вантажів. Розглянуто правила перевезення даного вантажу та особливості його упаковки. Доведено, що для організації ефективного та чіткого процесу доставки, особливо якщо доставка виконується на міжнародному рівні, та також передбачає організацію вантажно-розвантажувальних робіт, необхідно чітко сформувати транспортну та технологічну схему доставки вантажу. Перевезення соку у пляшках дозволяється будь-яким критим транспортом або у універсальних контейнерах, і обов'язково зберігати вантаж подалі від прямих сонячних променів. Сік має рідкий стан за своїм фізичним станом, тому його поміщають в упаковку відповідного розміру для зручності. Схема розміщення соку клітини розмірами $270 * 180 * 280$ мм і вагою 6,1 кг були розроблені на легкому європіддоні розмірами $1200 * 800$ мм Розглянуто можливі схеми розміщення піддонів з соком $1200 * 800 * 1540$ мм у напівпричепі SCHMITZ CARGOBULL SCS 18 із внутрішніми розмірами кузова $7720 * 2480 * 3000$ мм. Визначено, що оптимальною буде схема, в якій на кузов автомобіля розміщено 18 піддонів.

Ключові слова: вантаж, сік, палет, транспорт, транспортування.

JEL коди: F23, L62, L81.

Tables: 3; Figures: 3; References: 10

Language of the article: English

Jimepamypa

1. Govorukha, V. An Estimation of the Logistics Potential of Enterprises in the Region's Management / V. Govorukha, O. Kuchkova // Montenegrin Journal of Economics. - 2018. - Vol. 14. - No. 2. P. 79-89, doi.org/10.14254/1800-5845/2018.14-2.5.

2. Консерви. Соки та сокові продукти. Номенклатура: ДСТУ 4283.1:2007 - [Чинний від 2007 - 04 - 04]: Держспоживстандарт України, 2007 - (Національний стандарт України).

3. Консерви. Соки та сокові продукти. Вимоги: ДСТУ 4283.1:2007 - [Чинний від 2007 - 08 - 01]: Держспоживстандарт України, 2007 - (Національний стандарт України).

4. Крикавський, Ю. В. Логістика: основи теорії. - Львів : Львівський національний політехнічний університет, Інтелект-захід. - 2004. - 416 с.

5. Mukhtarova, K. S. Commercialization of Green Technologies: An Exploratory Literature Review / K. S. Mukhtarova, A. A. Trifilova, A. Zhidebekkyzy // Journal of International Studies. - 2016. Vol. 9. - No 3. - P. 75-87. http://doi.org/10.14254/2071-8330.2016/9-3/6.

6. Пиломатеріали хвойних порід. Технічні умови: ДСТУ 8486-86 - [Чинний від 1988 - 01 - 01] : Держспоживстандарт України, 1988 - (Національний стандарт України).

7. Пиломатеріали листових порід. Технічні умови: ДСТУ 2695-83 - [Чинний від 1984 - 01 - 01] : Держспоживстандарт України, 1984 - (Національний стандарт України).

8. Правила перевезення швидкопсувних вантажів: зі змінами від 08.06.2011 року / Міністерство транспорту України / Верховна Рада України - Офіц. Сайт. - Режим доступу : https://zakon.rada.gov.ua/laws/show/z1031-02.

9. Velychko, $O$. Logistical modelling of managerial decisions in social and marketing business systems / O. Velychko, L. Velychko // Journal of International Studies. - 2017. - Vol. 10. - No. 3. - P. 206219. http://dx.doi.org/10.14254/2071-8330.2017/10-3/15.

10. Zielińska, A. et al. The examples of reverse logistics application in inter-sector partnerships - good practices / A. Zielińska et al. // Journal of International Studies. - 2016. - Vol. 9. - No 3. - P. 279286. DOI: $10.14254 / 2071-8330.2016 / 9-3 / 22$. 